\title{
Effect of Preharvest Fruit Temperature on Ripening, Sugars, and Watercore Occurrence in Apples
}

\author{
Hisashi Yamada, Hirokazu Ohmura, Chizuru Arai, and Makoto Terui \\ Laboratory of Horticultural Science, Faculty of Agriculture, Niigata University, Ikarashi 2-8050, Niigata \\ 950-21, Japan
}

Additional index words. Malus domestica, 'Himekami', 'Fuji', sorbitol, maturity

\begin{abstract}
The influence of controlling temperature during apple (Malus domestica Borkh.) maturation on sugars, fruit maturity, and watercore occurrence was investigated in watercore-susceptible 'Himekami' and 'Fuji' apples. The incidence of watercore at $13 / 5$ and $23 / 15 \mathrm{C}$ was greater than at $33 / 25 \mathrm{C}$ or ambient temperatures in 'Himekami' apples in 1991 and was greater at $18 / 10 \mathrm{C}$ than at other temperatures in 'Fuji' apples in 1990. In 1992, the extent of watercore increased as fruit temperature decreased from 28 to $14 \mathrm{C}$ and 23 to $9 \mathrm{C}$ in 'Himekami' and 'Fuji' apples, respectively. Watercore occurrence affected by fruit temperature was not related to fruit maturity, as judged by ethylene evolution. The effect of fruit temperature on sorbitol was relatively small compared with that on other sugars, and no relationship was found between watercore development and sugars. These results suggest that fruit temperature affects watercore expression independently of fruit maturity or sorbitol metabolism in the fruit in watercore-susceptible apple cultivars.
\end{abstract}

Watercore is a physiological disorder of apple that develops while fruit are on the tree. Apple cultivars differ in watercore expression and, by using grafting combinations, Kollas (1968) demonstrated that the fruit were the site of genetic differences in watercore expression.

Watercore usually appears as fruit mature. Temperature is one of the most important factors that influence apple ripening. However, only a few reports on the relationship of temperature to watercore development are available. Fisher et al. (1930) observed that covering fruit with black cambric or transparent cellophane increased fruit temperature and induced watercore in 'Winter Banana', a watercore-susceptible apple cultivar, and 'Gano', a watercoreresistant apple cultivar. They also showed that fruit heated directly by a heater developed watercore accompanied with cooked and heatcrinkle symptoms. The high temperature resulting from a heat source is unusual during the maturation period for most apple cultivars, particularly late-maturing cultivars. On the other hand, Williams and Billingsley (1973) found that, in three seasons, watercore appeared in 'Delicious' apples when the minimum temperatures approached 4C. In apple growing regions, cold temperatures occur when fruit maturity is advanced. Marlow and Loescher (1984) associated watercore with maturity and cold temperatures.

Comparisons of chemical constituents between watercored and nonwatercored apples and between watercored and nonwatercored tissue in the same apple suggested that sorbitol metabolism was closely related to watercore development (Kollas, 1968; Williams, 1966; Williams et al., 1967). However, Marlow and Loescher (1984) stated that there was no evidence for any causative relationship between sorbitol metabolism and watercore development.

Recently, Tomana and Yamada (1988a) observed that watercore incidence was low when 'Jonathan' and 'Fuji' apples were grown in the southwestern districts of Japan, where preharvest temperature was higher than in other districts, even though fruit were harvested at similar maturity. They also showed that the content of reducing sugars and sucrose in the fruit had a positive and negative correlation, respectively, with preharvest temperatures. However, there was no clear relation between sorbitol and preharvest tem-

Received for publication 24 Jan. 1994. Accepted for publication 19 May 1994. We thank George C. Martin, Dept. of Pomology, Univ. of California, Davis, for reviewing this manuscript. The cost of publishing this paper was defrayed in part by the payment of page charges. Under postal regulations, this paper therefore must be hereby marked advertisement solely to indicate this fact. peratures. These temperature effects on sugar composition were verified experimentally by adjusting fruit temperature in the field (Yamada et al., 1988). These results suggest that watercore development in watercore-susceptible apples is altered by temperature, independent of sorbitol metabolism or fruit maturity.

In the present study, the effect of controlled preharvest fruit temperature on ripening, sugar content, and watercore development was investigated in watercore-susceptible 'Himekami' and 'Fuji' apples, which have different maturation dates. The purpose of these experiments was to determine the relationship between watercore occurrence and temperature, fruit maturity, and sorbitol metabolism.

\section{Materials and Methods}

In 1990, eighteen 4-year-old pot-grown trees of 'Fuji', a latematuring apple cultivar, were used for the experiment. The trees were grown outdoors until 17 Oct. and then transferred to the greenhouse for treatments. Each tree bore three or four fruit. Fruit temperature was controlled on 10 fruit at $8 / 0,18 / 10$, or $28 / 20 \mathrm{C}$ (day/night) from 18 Oct. to 18 Nov. Mean air temperature in the greenhouse during treatment was $20.8 \mathrm{C}$ (daily maximum) and 10.9C (daily minimum).

In 1991, three 4-year-old field-grown trees of 'Himekami', a middle-maturing apple cultivar, were sheltered with a frame covered with vinyl film that was open at the sides. The shelter protected the fruit and temperature-control system against rain. Fruit temperature was regulated on 11 fruit at 13/5, 23/15, or 33/ $25 \mathrm{C}$ from 3 to $25 \mathrm{Sept}$. Mean ambient temperature during treatment was 30.3C (daily maximum) and 19.7C (daily minimum).

In 1992, three 5-year-old field-grown 'Himekami' apple trees and two 5-year-old field-grown 'Fuji' apple trees were sheltered with a frame similar to that used in 1991. Fruit temperature was regulated at constant 14, 21, 28, or 35C in 'Himekami' and 9, 16, 23 , or 30C in 'Fuji'. The selected temperatures were intended to regulate watercore development. For 'Himekami', eight fruit were selected for each temperature treatment from 31 Aug. to 25 Sept. For 'Fuji', 10 fruit were selected per temperature treatment from 6 Oct. to 5 Nov. Mean ambient temperatures during treatment were 31.6C (daily maximum) and 18.0C (daily minimum) for 'Himekami' and 22.0C (daily maximum) and 11.1C (daily minimum) for 'Fuji'. 
Fruit temperature was controlled using modified techniques of Tomana et al. (1979a). Each fruit was enclosed in a transparent acrylic cylinder ( $3 \mathrm{~mm}$ wall thickness, $15 \mathrm{~cm}$ i.d. $\times 17 \mathrm{~cm}$ long) with both ends sealed with vinyl film (3 $\mathrm{mm}$ thick). Water or methanol regulated at a certain temperature in a constant-temperature bath was circulated in a vinyl tube $(9 \mathrm{~mm}$ in diameter) wound around the inside wall of the cylinder to maintain fruit temperature. Temperature was measured at equatorial sides of each treated fruit by a thermocouple connected to a recorder or by a thermometer inserted in a cylinder. Fruit temperature was checked every $30 \mathrm{~min}$ in the day and twice in the night for readjusting the circulating solvent temperature or solvent flow to each cylinder by a pinchcock. Fruit temperature was maintained to within $\pm 3 \mathrm{C}$ of the stated temperature.

When control fruit were considered mature by tasting and the number of days from full bloom, all fruit were harvested for subsequent evaluation. For 'Fuji' in 1990, two treated fruit at 28/ 20C abscised during treatment and the surface of five fruit at 8/0C turned brown as ice that formed on the surface of the vinyl tube touched the fruit during the $0 \mathrm{C}$ night temperature. For 'Himekami' in 1991, one fruit at $13 / 5 \mathrm{C}$ and three fruit at 23/15C abscised. Discarding the damaged and abscised fruit resulted in an uneven number of replications (five at 8/0C, ten at 18/10C, and eight at 28/
20C for 'Fuji' in 1990; ten at 13/5C, eight at 23/15C, and eleven at $33 / 25$ C for 'Himekami' in 1991).

After measuring fruit weight and volume, individual fruit were placed in a 1.6-liter gas-tight container for $1.5 \mathrm{~h}$. Then a 1-ml gas sample in each container was taken with a gas-tight syringe and ethylene evolution was quantified with a gas chromatograph (model 263-50; Hitachi, Tokyo) equipped with a flame ionization detector, an activated alumina column $(3 \mathrm{~mm}$ i.d. $\times 2 \mathrm{~m})$, and a peak integrator.

After ethylene analysis, fruit firmness was measured on opposite sides of the fruit using a fruit firmness tester with a 5-mm plunger. Ten skin disks (10 $\mathrm{mm}$ in diameter) were removed to measure anthocyanin at $530 \mathrm{~nm}$ after extraction in $10 \mathrm{ml}$ of $\mathrm{HCl}-$ methanol at 5C (Tomana et al., 1979a). Fruit were cut transversely and the degree of watercore in each fruit was assessed by visual rating $(0=$ none, $1=$ trace, $2=$ light, $3=$ moderate, $4=$ severe $)$. Expressed juice was collected from the flesh and soluble solids content (SSC) was measured using a hand-held refractometer. Total acidity was measured on a 1-ml sample of the juice titrated with $0.05 \mathrm{~N} \mathrm{NaOH}$. A portion of flesh from each fruit was separated into inner more-watercored tissue and outer less-watercored tissue, and then $10 \mathrm{~g}$ of each tissue was extracted overnight in $90 \%$ methanol. Sugar composition of flesh tissue was analyzed with the

Table 1. Effect of preharvest fruit temperature on watercore development, specific gravity, and water content in 'Himekami' apples.

\begin{tabular}{|c|c|c|c|c|}
\hline \multirow{2}{*}{$\begin{array}{l}\text { Fruit temp } \\
\left({ }^{\circ} \mathrm{C}\right)^{z}\end{array}$} & \multirow{2}{*}{$\begin{array}{c}\text { Watercore } \\
\text { rating }^{\mathrm{y}}\end{array}$} & \multirow{2}{*}{$\begin{array}{l}\text { Specific } \\
\text { gravity }\end{array}$} & \multicolumn{2}{|c|}{ Water content $\left(\mathrm{g} \cdot \mathrm{cm}^{-3}\right)$} \\
\hline & & & Inner flesh & Outer flesh \\
\hline \multicolumn{5}{|c|}{1991} \\
\hline $13 / 5$ & $2.4 \mathrm{a}^{\mathrm{x}}$ & $0.813 \mathrm{a}$ & & \\
\hline $23 / 15$ & $2.1 \mathrm{a}$ & $0.803 \mathrm{a}$ & & \\
\hline $33 / 25$ & $0.2 \mathrm{~b}$ & $0.790 \mathrm{~b}$ & & \\
\hline \multirow[t]{2}{*}{ Ambient } & $0.5 \mathrm{~b}$ & $0.806 \mathrm{a}$ & & \\
\hline & & 1992 & & \\
\hline 14 & $1.9 \mathrm{a}$ & $0.806 \mathrm{a}$ & $0.78 \mathrm{a}$ & $0.68 \mathrm{a}$ \\
\hline 21 & $0.9 \mathrm{~b}$ & $0.789 \mathrm{c}$ & $0.75 \mathrm{a}$ & $0.66 \mathrm{a}$ \\
\hline 28 & $0 \mathrm{c}$ & $0.796 \mathrm{bc}$ & $0.77 \mathrm{a}$ & $0.66 \mathrm{a}$ \\
\hline 35 & $0.2 \mathrm{c}$ & $0.799 \mathrm{ab}$ & $0.69 \mathrm{~b}$ & $0.62 \mathrm{~b}$ \\
\hline Ambient & $0 \mathrm{c}$ & $0.794 \mathrm{bc}$ & $0.77 \mathrm{a}$ & $0.67 \mathrm{a}$ \\
\hline
\end{tabular}

${ }^{\mathrm{z}}$ Day and night temperatures in 1991 and constant temperature in 1992.

$\mathrm{y}_{0}=$ None, $1=$ trace, $2=$ light, $3=$ moderate, $4=$ severe.

${ }^{x}$ Mean separation within columns and year by Duncan's multiple range test $(P=0.05)$.

Table 2. Effect of preharvest fruit temperature on watercore development, specific gravity, and water content in 'Fuji' apples.

\begin{tabular}{|c|c|c|c|c|}
\hline \multirow{2}{*}{$\begin{array}{l}\text { Fruit temp } \\
\left({ }^{\circ} \mathrm{C}\right)^{\mathrm{z}}\end{array}$} & \multirow{2}{*}{$\begin{array}{c}\text { Watercore } \\
\text { rating }^{\mathrm{y}}\end{array}$} & \multirow{2}{*}{$\begin{array}{c}\text { Specific } \\
\text { gravity }\end{array}$} & \multicolumn{2}{|c|}{ Water content $\left(\mathrm{g} \cdot \mathrm{cm}^{-3}\right)$} \\
\hline & & & Inner flesh & Outer flesh \\
\hline & & 1990 & & \\
\hline $8 / 0$ & $0.4 b^{x}$ & $0.844 \mathrm{c}$ & & \\
\hline $18 / 10$ & $1.5 \mathrm{a}$ & $0.880 \mathrm{a}$ & & \\
\hline $28 / 20$ & $0.1 \mathrm{~b}$ & $0.870 \mathrm{~b}$ & & \\
\hline \multirow[t]{2}{*}{ Ambient } & $0.6 \mathrm{~b}$ & $0.869 \mathrm{~b}$ & & \\
\hline & & 1992 & & \\
\hline 9 & $2.5 \mathrm{a}$ & $0.864 \mathrm{a}$ & $0.83 \mathrm{a}$ & $0.71 \mathrm{a}$ \\
\hline 16 & $1.9 \mathrm{~b}$ & $0.858 \mathrm{a}$ & $0.81 \mathrm{a}$ & $0.69 \mathrm{a}$ \\
\hline 23 & $0 \mathrm{e}$ & $0.853 \mathrm{a}$ & $0.79 \mathrm{a}$ & $0.68 \mathrm{a}$ \\
\hline 30 & $0.6 \mathrm{~d}$ & $0.854 \mathrm{a}$ & $0.73 \mathrm{~b}$ & $0.68 \mathrm{a}$ \\
\hline Ambient & $1.3 \mathrm{c}$ & $0.858 \mathrm{a}$ & $0.79 \mathrm{a}$ & $0.67 \mathrm{a}$ \\
\hline
\end{tabular}

${ }^{\mathrm{Z}}$ Day and night temperatures in 1990 and constant temperature in 1992.

${ }^{y_{0}}=$ None, $1=$ trace, $2=$ light, $3=$ moderate, $4=$ severe.

${ }^{\mathrm{x}}$ Mean separation within columns and year by Duncan's multiple range test $(P=0.05)$. 
gas chromatograph described above using a silicone column (3 $\mathrm{mm}$ i.d. $\times 2 \mathrm{~m}$ ) after silylating the methanolic extracts with a trimethylsilylating reagent (Tomana and Yamada, 1988a). An equivalent of water was added to the dried residue after extracting sugars and stirred to a paste in a boiling water bath. Starch was extracted in $4.6 \mathrm{~N}$ perchloric acid from the paste and hydrolyzed into glucose in $0.56 \mathrm{~N}$ perchloric acid for $2 \mathrm{~h}$ in boiling water. After neutralization with $1 \mathrm{~N} \mathrm{NaOH}$, glucose concentration was determined by the anthrone method (Chachin, 1981).

Specific gravity was determined by dividing fruit weight by fruit volume. In 1992, an equivalent volume of flesh tissue was taken from inner and outer parts of flesh of each fruit separately using knives and a corkborer and the tissue was dried after being weighed to determine water content on a per-volume basis.

\section{Results}

At the start of every treatment, no watercore expression was found in more than 10 fruit sampled (data not shown). In 'Himekami' apples, watercore ratings at $13 / 5$ and $23 / 15 \mathrm{C}$ were significantly higher than those at 33/25C and ambient temperatures (Table 1). Specific gravity was low at $33 / 25 \mathrm{C}$ compared with other treatments in 1991. In 1992, the watercore rating increased as fruit temperature decreased from 28 to $14 \mathrm{C}$ (Table 1 ). There was no watercored fruit at $28 \mathrm{C}$ and ambient temperatures, while a slight watercore throughout the flesh occurred at 35C. Fruit at 21 and $14 \mathrm{C}$ expressed watercore mainly at the core line. Specific gravity was highest at $14 \mathrm{C}$ and lowest at $21 \mathrm{C}$, while water content was lower at $35 \mathrm{C}$ than at other temperatures. Fruit at $35 \mathrm{C}$ shriveled and had sponge-like flesh.

In 'Fuji' apples, the watercore rating and specific gravity at 18/ 10C were higher than those at other temperatures in 1990 (Table 2). In 1992, fruit temperature at $23 \mathrm{C}$ inhibited watercore development completely and the mean watercore rating increased as fruit temperature decreased from 23 to $9 \mathrm{C}$. Some fruit at $30 \mathrm{C}$ exhibited crinkling and slight watercore. Water content of inner flesh at 30C was significantly lower than that at other temperatures, although there was no clear difference among treatments in specific gravity and water content of outer flesh.

In 'Himekami' apples, fruit weight at $23 / 15$ and $33 / 25 \mathrm{C}$ was

Table 3. Effect of preharvest fruit temperature on ripening and quality in 'Himekami' apples.

\begin{tabular}{|c|c|c|c|c|c|c|c|c|c|c|}
\hline \multirow{3}{*}{$\begin{array}{l}\text { Fruit } \\
\text { temp }\left({ }^{\circ} \mathrm{C}\right)^{y}\end{array}$} & \multirow{3}{*}{$\begin{array}{l}\text { Fruit } \\
\text { wt } \\
(\mathrm{g})\end{array}$} & \multirow{3}{*}{$\begin{array}{c}\text { Ethylene } \\
\text { evolution } \\
\left(\mu \mathrm{l} \cdot \mathrm{kg}^{-1} \cdot \mathrm{h}^{-1}\right)\end{array}$} & \multirow{3}{*}{$\begin{array}{l}\text { SSC } \\
(\%)\end{array}$} & \multirow{3}{*}{$\begin{array}{l}\text { Titratable } \\
\text { acidity } \\
\left(\mathrm{mg} \cdot \mathrm{ml}^{-1}\right)\end{array}$} & \multirow{3}{*}{$\begin{array}{c}\text { Flesh } \\
\text { firmness } \\
(\mathrm{N})\end{array}$} & \multirow{3}{*}{$\begin{array}{c}\text { Anthocyanin } \\
\text { content } \\
\left(\mathrm{OD}_{530 \mathrm{~nm}}\right)\end{array}$} & \multicolumn{2}{|c|}{ Starch content } & \multicolumn{2}{|c|}{ Total sugars $^{\mathrm{z}}$} \\
\hline & & & & & & & \multicolumn{4}{|c|}{$\left(\mathrm{mg} \cdot \mathrm{g}^{-1}\right.$ fresh wt $)$} \\
\hline & & & & & & & Inner $^{x}$ & Outer & Inner & Outer \\
\hline & & & & & 1991 & & & & & \\
\hline $13 / 5$ & $239 b^{w}$ & $0.99 \mathrm{c}$ & $14.2 \mathrm{c}$ & $5.4 \mathrm{~b}$ & $68.0 \mathrm{a}$ & $0.80 \mathrm{a}$ & $1.4 \mathrm{a}$ & $2.0 \mathrm{a}$ & $134 \mathrm{c}$ & $152 \mathrm{~b}$ \\
\hline $23 / 15$ & 326 a & $1.64 \mathrm{~b}$ & $15.5 \mathrm{a}$ & $7.4 \mathrm{a}$ & $65.2 \mathrm{a}$ & $0.71 \mathrm{a}$ & $1.2 \mathrm{a}$ & $2.0 \mathrm{a}$ & $145 \mathrm{~b}$ & $157 \mathrm{ab}$ \\
\hline $33 / 25$ & $312 \mathrm{a}$ & $1.83 \mathrm{ab}$ & $14.8 \mathrm{~b}$ & $3.6 \mathrm{c}$ & $62.0 \mathrm{a}$ & $0.17 \mathrm{~b}$ & $1.3 \mathrm{a}$ & $1.2 \mathrm{~b}$ & $152 \mathrm{a}$ & $157 \mathrm{ab}$ \\
\hline Ambient & $255 \mathrm{~b}$ & $2.13 \mathrm{a}$ & $15.0 \mathrm{ab}$ & $5.5 \mathrm{~b}$ & $\begin{array}{c}65.6 \mathrm{a} \\
1992\end{array}$ & $0.77 \mathrm{a}$ & $1.6 \mathrm{a}$ & $1.9 \mathrm{a}$ & $152 \mathrm{a}$ & $161 \mathrm{a}$ \\
\hline 14 & $261 \mathrm{c}$ & $0.68 \mathrm{c}$ & $15.1 \mathrm{ab}$ & $7.2 \mathrm{a}$ & $67.1 \mathrm{~b}$ & $0.74 \mathrm{a}$ & $1.7 \mathrm{~b}$ & $2.4 \mathrm{~b}$ & $144 \mathrm{a}$ & $156 \mathrm{a}$ \\
\hline 21 & $306 a b$ & $1.83 \mathrm{ab}$ & $14.7 \mathrm{bc}$ & $4.9 \mathrm{~b}$ & $60.2 \mathrm{c}$ & $0.40 \mathrm{~b}$ & $1.8 \mathrm{~b}$ & $1.8 \mathrm{c}$ & $143 \mathrm{a}$ & $157 \mathrm{a}$ \\
\hline 28 & $313 \mathrm{a}$ & $1.69 \mathrm{~b}$ & $14.3 \mathrm{c}$ & $3.5 \mathrm{c}$ & $62.6 \mathrm{bc}$ & $0.09 \mathrm{c}$ & $2.0 \mathrm{~b}$ & $1.6 \mathrm{c}$ & $142 \mathrm{a}$ & $149 \mathrm{a}$ \\
\hline 35 & $247 \mathrm{c}$ & $0.86 \mathrm{c}$ & $15.4 \mathrm{a}$ & $2.6 \mathrm{~d}$ & $73.3 \mathrm{a}$ & $0.06 \mathrm{c}$ & $3.1 \mathrm{a}$ & $3.1 \mathrm{a}$ & $153 \mathrm{a}$ & $162 \mathrm{a}$ \\
\hline Ambient & $273 \mathrm{bc}$ & $2.20 \mathrm{a}$ & $15.2 \mathrm{ab}$ & $5.2 \mathrm{~b}$ & $63.1 \mathrm{bc}$ & $0.40 \mathrm{~b}$ & $1.7 \mathrm{~b}$ & $2.1 \mathrm{bc}$ & $146 \mathrm{a}$ & $159 \mathrm{a}$ \\
\hline
\end{tabular}

${ }^{\mathrm{z} C a l c u l a t e d ~ f r o m ~ e a c h ~ s u g a r ~ c o n t e n t ~ d e t e r m i n e d ~ b y ~ g a s ~ c h r o m a t o g r a p h y . ~}$

y Day and night temperatures in 1991 and constant temperature in 1992.

xInner $=$ inner flesh, outer $=$ outer flesh.

${ }^{w}$ Mean separation within columns and year by Duncan's multiple range test $(P=0.05)$.

Table 4. Effect of preharvest fruit temperature on ripening and quality in 'Fuji' apples.

\begin{tabular}{|c|c|c|c|c|c|c|c|c|c|c|}
\hline \multirow{3}{*}{$\begin{array}{l}\text { Fruit } \\
\text { temp }\left({ }^{\circ} \mathrm{C}\right)^{\mathrm{y}}\end{array}$} & \multirow{3}{*}{$\begin{array}{l}\text { Fruit } \\
\text { wt } \\
(\mathrm{g})\end{array}$} & \multirow{3}{*}{$\begin{array}{c}\text { Ethylene } \\
\text { evolution } \\
\left(\mu \mathrm{l} \cdot \mathrm{kg}^{-1} \cdot \mathrm{h}^{-1}\right)\end{array}$} & \multirow{3}{*}{$\begin{array}{l}\text { SSC } \\
(\%)\end{array}$} & \multirow{3}{*}{$\begin{array}{l}\text { Titratable } \\
\text { acidity } \\
\left(\mathrm{mg} \cdot \mathrm{ml}^{-1}\right)\end{array}$} & \multirow{3}{*}{$\begin{array}{c}\text { Flesh } \\
\text { firmness } \\
(\mathrm{N})\end{array}$} & \multirow{3}{*}{$\begin{array}{c}\text { Anthocyanin } \\
\text { content } \\
\left(\mathrm{OD}_{530 \mathrm{~nm}}\right)\end{array}$} & \multicolumn{2}{|c|}{ Starch content } & \multicolumn{2}{|c|}{ Total sugars ${ }^{\mathrm{z}}$} \\
\hline & & & & & & & \multicolumn{4}{|c|}{$\left(\mathrm{mg} \cdot \mathrm{g}^{-1}\right.$ fresh wt) } \\
\hline & & & & & & & Inner $^{x}$ & Outer & Inner & Outer \\
\hline & & & & & 1990 & & & & & \\
\hline $8 / 0$ & $289 a^{w}$ & $0.49 \mathrm{a}$ & $14.9 \mathrm{a}$ & $4.1 \mathrm{a}$ & $71.8 \mathrm{c}$ & $0.15 \mathrm{c}$ & $1.3 \mathrm{a}$ & $1.9 \mathrm{a}$ & $140 \mathrm{a}$ & $144 \mathrm{a}$ \\
\hline $18 / 10$ & 335 a & $0.33 \mathrm{a}$ & $15.1 \mathrm{a}$ & $4.0 \mathrm{a}$ & $81.0 \mathrm{~b}$ & $0.25 \mathrm{~b}$ & $1.0 \mathrm{~b}$ & $1.2 \mathrm{a}$ & $146 \mathrm{a}$ & $151 \mathrm{a}$ \\
\hline $28 / 20$ & $318 \mathrm{a}$ & $0.50 \mathrm{a}$ & $15.8 \mathrm{a}$ & $3.5 \mathrm{a}$ & $87.5 \mathrm{a}$ & $0.14 \mathrm{c}$ & $1.5 \mathrm{a}$ & $1.7 \mathrm{a}$ & $153 \mathrm{a}$ & $165 \mathrm{a}$ \\
\hline Ambient & $282 \mathrm{a}$ & $0.52 \mathrm{a}$ & $16.4 \mathrm{a}$ & $4.5 \mathrm{a}$ & $\begin{array}{c}88.4 \mathrm{a} \\
1992\end{array}$ & $0.35 \mathrm{a}$ & $1.6 \mathrm{a}$ & $1.9 \mathrm{a}$ & $155 \mathrm{a}$ & $163 \mathrm{a}$ \\
\hline 9 & $318 \mathrm{a}$ & $0.15 \mathrm{~b}$ & $14.4 \mathrm{a}$ & $4.3 \mathrm{a}$ & $77.8 \mathrm{~b}$ & $0.60 \mathrm{a}$ & $2.0 \mathrm{~b}$ & $3.4 \mathrm{a}$ & $133 \mathrm{bc}$ & $145 \mathrm{~b}$ \\
\hline 16 & $341 \mathrm{a}$ & $0.47 \mathrm{a}$ & $14.4 \mathrm{a}$ & $3.6 \mathrm{~b}$ & $72.5 \mathrm{bc}$ & $0.36 \mathrm{~b}$ & $1.6 \mathrm{~b}$ & $2.3 \mathrm{~b}$ & $134 \mathrm{bc}$ & $144 \mathrm{~b}$ \\
\hline 23 & $325 \mathrm{a}$ & $0.24 \mathrm{~b}$ & $14.3 \mathrm{a}$ & $3.1 \mathrm{c}$ & $72.4 \mathrm{bc}$ & $0.12 \mathrm{c}$ & $2.1 \mathrm{~b}$ & $2.3 \mathrm{~b}$ & $130 \mathrm{c}$ & $146 \mathrm{~b}$ \\
\hline 30 & $280 \mathrm{~b}$ & $0.15 \mathrm{~b}$ & $15.3 \mathrm{a}$ & $1.9 \mathrm{~d}$ & $84.3 \mathrm{a}$ & $0.10 \mathrm{c}$ & $2.8 \mathrm{a}$ & $2.8 \mathrm{~b}$ & $148 \mathrm{a}$ & $157 \mathrm{a}$ \\
\hline Ambient & $312 a b$ & $0.32 \mathrm{ab}$ & $15.1 \mathrm{a}$ & $3.8 \mathrm{~b}$ & $70.1 \mathrm{c}$ & $0.40 \mathrm{~b}$ & $1.7 \mathrm{~b}$ & $2.7 \mathrm{~b}$ & $139 \mathrm{~b}$ & $154 \mathrm{ab}$ \\
\hline
\end{tabular}

${ }^{\mathrm{z}}$ Calculated from each sugar content determined by gas chromatography.

yDay and night temperatures in 1990 and constant temperature in 1992.

xInner $=$ inner flesh, outer $=$ outer flesh.

wMean separation within columns and year by Duncan's multiple range test $(P=0.05)$. 
greater than that at $13 / 5 \mathrm{C}$ and ambient temperatures in 1991 (Table $3)$. Ethylene evolution was highest at ambient temperatures and lowest at 13/5C. SSC was lowest at 13/5C and titratable acidity and anthocyanin content were lowest at the highest fruit temperature (33/25C). There was no significant difference in flesh firmness among treatments. Starch content in outer flesh at $33 / 25 \mathrm{C}$ was lower than that at other temperatures, while there was no clear difference in starch in inner flesh among fruit temperatures. Total sugars at ambient temperature was higher than that at $13 / 5 \mathrm{C}$ in inner and outer flesh. In 1992, fruit weight at 21 and $28 \mathrm{C}$ was greater than that at 14 and $35 \mathrm{C}$ (Table 3). Ethylene evolution at 14 and $35 \mathrm{C}$ was lower than that at other temperatures. SSC was lowest at $28 \mathrm{C}$ and highest at $35 \mathrm{C}$. Acidity and anthocyanin increased as fruit temperature decreased from 35 or $28 \mathrm{C}$ to $14 \mathrm{C}$. Flesh firmness and starch content in either inner or outer flesh were highest at 35C. There was no significant difference among treatments in total sugars in 1992 (Table 3).

In 'Fuji' apples, there was no significant difference among fruit temperatures in fruit weight, ethylene evolution, SSC, titratable acidity, and total sugars in 1990 (Table 4). Flesh firmness was highest at ambient and 28/20C and decreased as fruit temperature decreased from 28/20 to 8/0C. Anthocyanin content was highest at ambient temperature followed by $18 / 10 \mathrm{C}$. Starch content in inner flesh at 18/10C was lower than that at other treatments, while no significant difference among treatments was found in outer flesh. In 1992, fruit weight was lowest at 30C and ethylene evolution was highest at $16 \mathrm{C}$ (Table 4). No significant difference was found among treatments in SSC. Titratable acidity and anthocyanin content increased with decreased fruit temperature from 30 or 23 to $9 \mathrm{C}$. Flesh firmness was highest at the highest fruit temperature (30C). Starch content in inner flesh was highest at 30C, while that in outer flesh was highest at 9C. Total sugars was highest at 30C in either inner or outer flesh tissue (Table 4).

'Himekami' apples at 33/25C had highest fructose and glucose content and lowest sucrose content in inner and outer flesh in 1991 (Fig. $1 \mathrm{~A}$ and B). Sorbitol content at $23 / 15 \mathrm{C}$ was higher than that at $13 / 5 \mathrm{C}$ in outer flesh (Fig. 1B), although no difference was found among fruit temperatures in inner flesh (Fig. 1A). In 1992, fructose and glucose in inner flesh increased as fruit temperature increased from 21 to $35 \mathrm{C}$ and those in outer flesh were higher at $35 \mathrm{C}$ compared with other temperatures (Fig. $1 \mathrm{C}$ and D). Contrary to reducing sugars, sucrose content decreased with increased temperature from 21 to $35 \mathrm{C}$ in both flesh tissues. On the other hand, sorbitol was highest at $35 \mathrm{C}$ in either inner or outer flesh, although the differences were relatively small compared with those in other sugars (Fig. $1 \mathrm{C}$ and D).

In 'Fuji' apples, fructose and glucose content at 28/20C was higher than that at $18 / 10$ and 8/0C in both flesh tissues (Fig. $2 \mathrm{~A}$ and B), while there was no significant difference among treatments in sorbitol and sucrose content in 1990 (Fig. 2 A and B). In 1992, fructose and sorbitol content at 30C was higher than that at other temperatures in both flesh tissues (Fig. 2 C and D). Glucose content

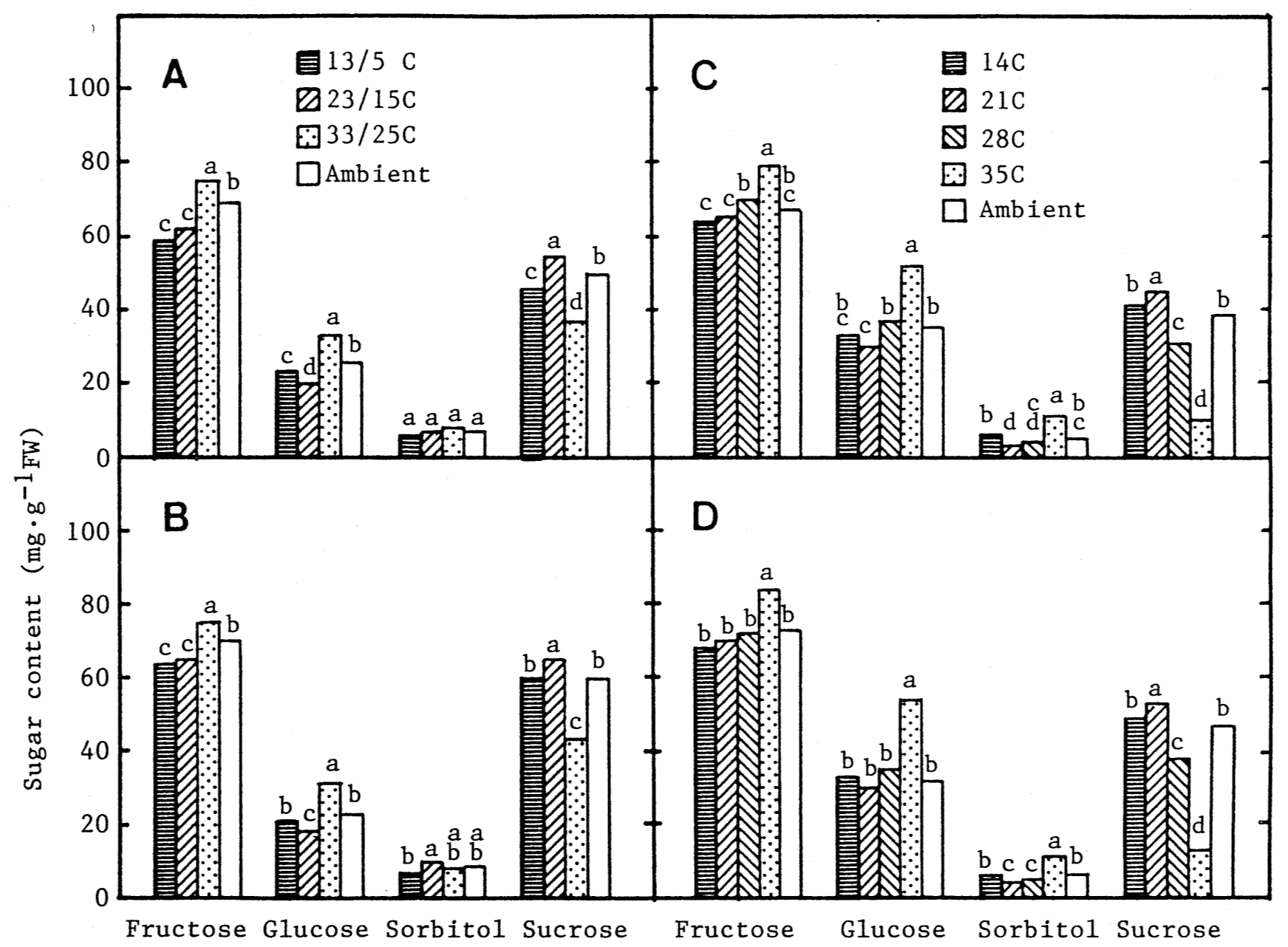

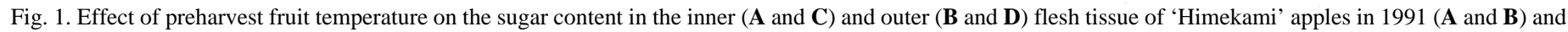
1992 (C and D). Mean separation within each sugar, tissue, and year by Duncan's multiple range test $(P=0.05)$. 
increased as fruit temperature increased from 9 to $30 \mathrm{C}$, while sucrose decreased as temperature increased from 16 to $30 \mathrm{C}$ (Fig. $2 \mathrm{C}$ and D). Each sugar content at ambient temperature was similar to that at 16 or $23 \mathrm{C}$ in 1992 (Fig. $2 \mathrm{C}$ and D).

\section{Discussion}

Tomana and Yamada (1988a) observed less watercore in apples produced in the southwestern districts of Japan, where temperature at the maturing stage was higher than in the main apple production areas of Japan. The results reported here show that fruit temperature during the month before harvest had a marked effect on watercore development. In particular, the results in 1992 show that watercore rating increased as fruit temperature decreased from 28 to $14 \mathrm{C}$ in 'Himekami' apples and from 23 to $9 \mathrm{C}$ in 'Fuji' apples (Tables 1 and 2). Since no watercore expression was found in the fruit at the start of each temperature treatment, watercore observed at the end of treatment was considered to occur as a direct result of temperature. The comparison between the gradient temperatures in 1990 or 1991 and constant temperatures in 1992 suggests that a difference between day and night temperature is not required for watercore development as suggested for some other ripening characteristics (Sugiura et al., 1991; Tomana et al., 1979a, 1979b; Utsunomiya et al., 1982; Yamada et al., 1988). Watercore inhibition at 28 and $23 \mathrm{C}$ supported the field observations by Tomana and Yamada (1988a) described above. Westwood (1993) also stated that 'Delicious', a watercore-susceptible apple cultivar, would show no watercore at higher temperatures. Fruit treated at above $30 \mathrm{C}$ developed a slight watercore with a different expression from those treated at lower temperatures. Fisher et al. (1930) found that increasing fruit temperature to above $40 \mathrm{C}$ by covering fruit with black cambric or transparent cellophane or heating fruit with an electric heater increased watercore in watercore-susceptible 'Winter Banana' apples. The treatments, however, produced watercore even in watercore- resistant 'Gano' apples (Fisher et al., 1930). We also observed the occurrence of watercore in some watercoreresistant cultivars at the immature stage in the summer or when fruit were treated at high temperatures above 33C (data not shown). These observations suggest that watercore induced at a higher temperature may occur via a different mechanism from that induced at a lower temperature during maturation.

The lower water content at 35C in 'Himekami' apples and at $30 \mathrm{C}$ in 'Fuji' apples suggested that high temperatures promoted water loss from the fruit (Tables 1 and 2). Fruit at these highest temperatures, however, had relatively higher specific gravity. Since smaller fruit tend to be more dense (Fidler et al., 1973), the inhibition of fruit growth at these highest temperatures (Tables 3 and 4) may affect specific gravity. In general, fruit with the highest watercore ratings had the highest specific gravity and highest water content, although the differences were not significant in some cases (Tables 1 and 2). The difference in fruit growth as affected by fruit temperature (Tables 3 and 4) or relatively moder-

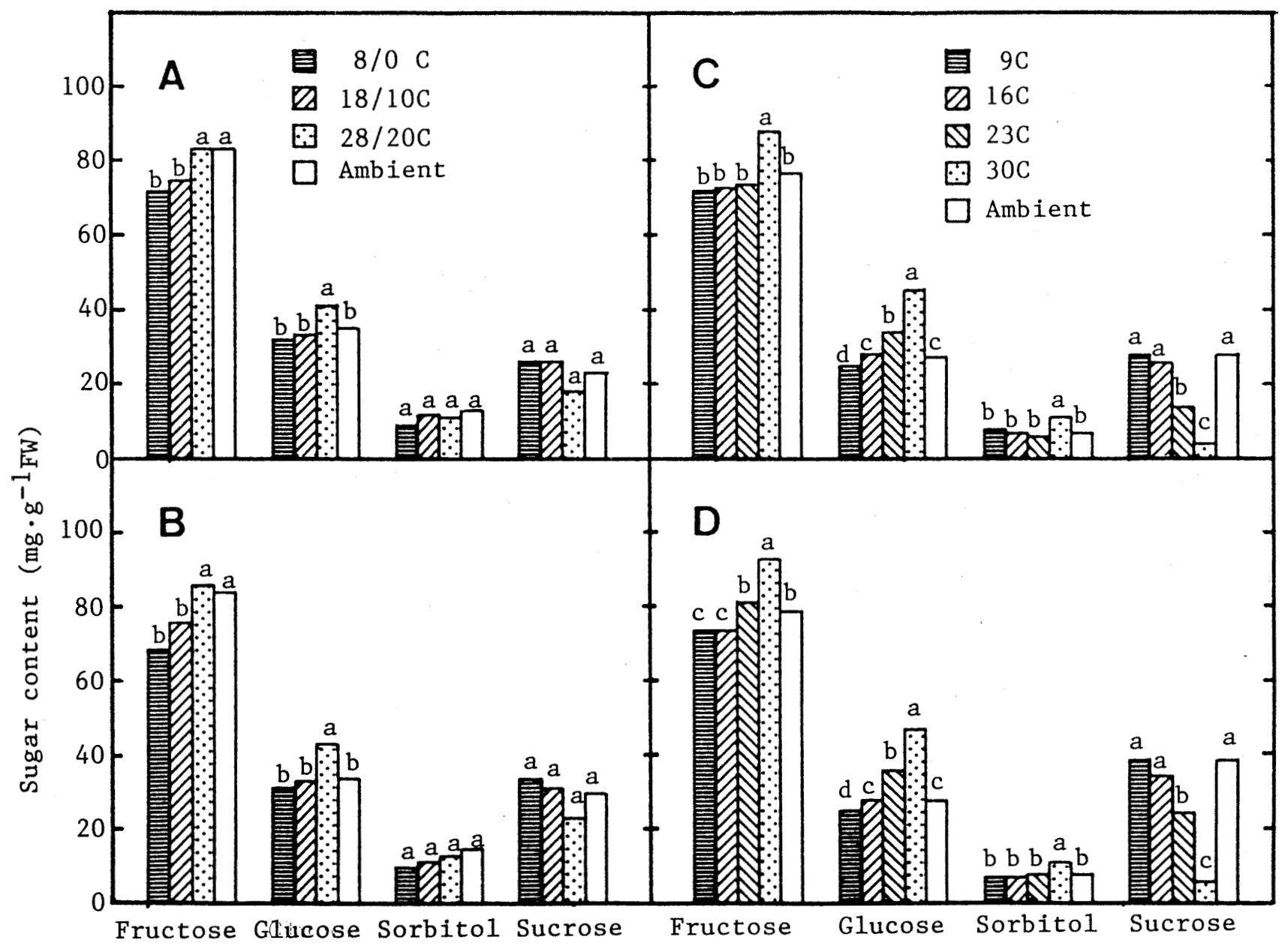

Fig. 2. Effect of preharvest fruit temperature on the sugar content in the inner (A and $\mathbf{C})$ and outer (B and $\mathbf{D})$ flesh tissue of 'Fuji' apples in 1990 (A and $\mathbf{B})$ and 1992 $(\mathbf{C}$ and $\mathbf{D})$. Mean separation within each sugar, tissue, and year by Duncan's multiple range test $(P=0.05)$. 
ate watercore at a rating of $<2.5$ (Tables 1 and 2) may result in the small differences in specific gravity and water content among temperatures.

It is well documented that ambient temperatures affect fruit growth and ripening. It has also been shown that, by using enclosures around individual fruit, fruit temperature can affect fruit ripening independently of tree temperature (Sugiura et al., 1991; Tomana et al., 1979a, 1979b; Utsunomiya et al., 1982; Yamada et al., 1988). In general, as apples mature, SSC, total sugars, and anthocyanin content increase and total acids, flesh firmness, and starch content decrease. However, it has been suggested that temperature has differential effects on each of these factors, resulting in difficulties when comparing the maturity of fruit treated at different temperatures or grown under different ambient temperatures (Tomana and Yamada, 1988a; Yamada et al., 1988). The results reported here also show the differential effect of fruit temperature on two maturity indexes. Acidity and anthocyanin decreased as fruit temperature increased in 1992 (Tables 3 and 4). The strong effect of temperature on acidity or anthocyanin accumulation has been demonstrated with grapes (Tomana et al., 1979a, 1979b) and apples (Blankenship, 1987; Faragher, 1983; Yamada et al., 1988). The fruit temperature effect on SSC was not significant in 'Fuji' and not consistent in the 2 years in 'Himekami' apples (Tables 3 and 4). Significantly higher flesh firmness at the highest temperatures (35 and 30C) in 1992 in both cultivars seems to result from tissue deterioration induced by long-term exposure to high temperature. Also, starch breakdown was inhibited at 35 and 30C (Tables 3 and 4).

In climacteric fruit, including apples, ethylene evolution or internal ethylene concentration has been used to indicate the physiological maturity of the fruit (Kato and Sato, 1978; Kato et al., 1977; Kingston, 1992; Sfakiotakis and Dilley, 1973). Watercoreaffected apples had higher ethylene concentration and evolution than unaffected fruit after harvest (Kato and Sato, 1978; Wang and Faust, 1992). Many other reports consisting of observations and experimental data have noted the relationship between watercore development and maturation (Marlow and Loescher, 1984). However, there are few reports on ethylene comparisons of apples grown under different temperatures. Sfakiotakis and Dilley (1973) indicated that ethylene levels in apples immediately after harvest were similar to those in fruit on the tree during development and ripening. Therefore, ethylene evolution measured after fruit temperature treatments may reflect the maturity of the fruit on the trees. In our studies, if the average ambient or day and night temperature was used, fruit maturities at 19 to 29C in 'Himekami' apples and at $\approx 16 \mathrm{C}$ in 'Fuji' apples were considered to be advanced more than those at other lower or higher temperatures (Tables 3 and 4). Starch content, which was greatest at the highest or lowest temperature in 1992, supported, in part, this viewpoint (Tables 3 and 4). Therefore, no clear relation was found between fruit maturity and the extent of watercore in either 'Himekami' or 'Fuji' apples (Tables 3 vs. 1 and 4 vs. 2). These results suggest that temperature directly affects watercore development on the tree without being mediated through an influence on fruit maturity. Further, this conclusion is supported by our previous observation that apples grown in districts with different preharvest temperatures showed different levels of watercore development, even though the fruit were harvested at a similar stage of maturity (Tomana and Yamada, 1988a).

Since Williams (1966) found watercored apples to be higher in sorbitol content than nonwatercored apples, many studies on the role of sorbitol metabolism in watercore occurrence have been done. Most of the studies linking watercore to sorbitol consisted of comparisons between watercore-susceptible and watercore-resistant cultivars or between immature and mature fruit of the same cultivar at the same location. Few investigations have been conducted with apples grown under different environmental conditions. However, Tomana and Yamada (1988a, 1988b) recently found high positive or negative correlations between the amount of reducing sugar or sucrose accumulation, respectively, and temperature during maturation in three apple cultivars grown in several districts in Japan. There was no clear relationship between temperature and sorbitol content. In our investigations, it was difficult to provide definitive evidence for the role of sorbitol in watercore development in watercore-susceptible apples, since the onset of watercore was markedly affected by fruit temperature without involving any related changes in sorbitol content (Table 1 vs. Fig. 1, Table 2 vs. Fig. 2). Marlow and Loescher (1984) also concluded that there was no evidence for any causative relationship between sorbitol metabolism and watercore.

In the 1992 experiments, sorbitol concentrations at the highest temperatures ( 30 and $35 \mathrm{C}$ ) were significantly higher than those at lower or ambient temperatures (Figs. 1 and 2). Apples at these high fruit temperatures developed a slight but different watercore. At 35 and 30C, watercore occurred throughout the flesh, whereas it occurred only in the vascular bundles at lower temperatures. The changes in membrane permeability induced by excessively high fruit temperature may account for the appearance of watercore symptoms and the elevated sorbitol content at these high temperatures, as discussed by Marlow and Loescher (1984).

With regard to other sugars, including total sugars, no clear relationship was found between the changes in sugar content and the watercore ratings affected by fruit temperatures (Table 1 vs. Fig. 1, Table 2 vs. Fig. 2). This suggests that these sugars do not contribute to watercore. In watercored fruit at lower fruit temperatures, there was no marked difference in sugar content between inner and outer flesh tissues (Figs. 1 and 2). This casts further doubt on the role of sugar in inducing watercore.

In conclusion, results of our experiments indicate that watercore development as affected by fruit temperature is not always associated with maturity or sorbitol content in watercore-susceptible apple cultivars. The physiological mechanism of watercore development remains unclear. Finally, this study shows that our fruit temperature-control system could be useful for further research on watercore.

\section{Literature Cited}

Blankenship, S.M. 1987. Night-temperature effects on rate of apple fruit maturation and fruit quality. Sci. Hort. 33:205-212.

Chachin, K. 1981. Carbohydrates, p. 156-162. In: S. Nakagawa, Y. Ohsawa, Y. Sakanishi, T. Iwata, and R. Takahashi (eds.). Experiment and practice in horticulture. Yokendo, Tokyo.

Faragher, J.D. 1983. Temperature regulation of anthocyanin accumulation in apple skin. J. Expt. Bot. 34:1291-1298.

Fidler, J.C., B.G. Wilkinson, K.L. Edney, and R.O. Sharples. 1973. The biology of apple and pear storage. Commonwealth Bur. Hort. Plantation Crops, Commonwealth Agr. Bur., East Malling, England. Res. Rev. 3. Fisher, D.F., C.P. Harley, and C. Brooks. 1930. The influence of temperature on the development of watercore. Proc. Amer. Soc. Hort. Sci. 27:276-280.

Kato, K., K. Abe, and R. Sato. 1977. The ripening of apple fruits I. Changes in respiration, $\mathrm{C}_{2} \mathrm{H}_{4}$ evolution and internal $\mathrm{C}_{2} \mathrm{H}_{4}$ concentration during maturation and ripening. J. Jpn. Soc. Hort. Sci. 46:380-388.

Kato, K. and R. Sato. 1978. The ripening of apple fruits II. Interrelations of respiration rate, $\mathrm{C}_{2} \mathrm{H}_{4}$ evolution rate and internal gas concentrations, and their relations to specific gravity or watercore during maturation and ripening. J. Jpn. Soc. Hort. Sci. 46:530-540. 
Kingston, C.M. 1992. Maturity indices for apple and pear. Hort. Rev. 13:407-432.

Kollas, D.A. 1968. Physiology of watercore development in apple. PhD thesis. Cornell Univ., Ithaca, N.Y.

Marlow, G.C. and W.H. Loescher. 1984. Watercore. Hort. Rev. 6:189-251. Sfakiotakis, E.M. and D.R. Dilley. 1973. Internal ethylene concentrations in apple fruits attached to or detached from the tree. J. Amer. Soc. Hort. Sci. 98:501-503.

Sugiura, A., G.H. Zheng, and K. Yonemori. 1991. Growth and ripening of persimmon fruit at controlled temperatures during growth stage III. HortScience 26:574-576.

Tomana, T., N. Utsunomiya, and I. Kataoka. 1979a. The effect of environmental temperatures on fruit ripening on the tree. I. The effect of temperatures around whole vines and clusters on the ripening of 'Delaware' grapes. Studies Inst. Hort. Kyoto Univ. 9:1-5.

Tomana, T., N. Utsunomiya, and I. Kataoka. 1979b. The effect of environmental temperatures on fruit ripening on the tree. II. The effect of temperatures around whole vines and clusters on the coloration of 'Kyoho' grapes. J. Jpn. Soc. Hort. Sci. 48:261-266.

Tomana, T. and H. Yamada. 1988a. Relationship between temperature and fruit quality of apple cultivars grown at different locations. J. Jpn. Soc. Hort. Sci. 56:391-397.
Tomana, T. and H. Yamada. 1988b. Changes in sugar composition during maturation stage of apple fruits grown at different locations. J. Jpn. Soc. Hort. Sci. 57:178-183.

Utsunomiya, N., H. Yamada, I. Kataoka, and T. Tomana. 1982. The effect of fruit temperatures on the maturation of satsuma mandarin (Citrus unshiu Marc.) fruits. J. Jpn. Soc. Hort. Sci. 51:135-141.

Wang, S.Y. and M. Faust. 1992. Ethylene biosynthesis and polyamine accumulation in apples with watercore. J. Amer. Soc. Hort. Sci. 117:133138.

Westwood, M.N. 1993. Temperate-zone pomology: Physiology and culture. 3rd ed. Timber Press, Portland, Ore.

Williams, M.W. 1966. Relationship of sugars and sorbitol to watercore in apples. Proc. Amer. Soc. Hort. Sci. 88:67-75.

Williams, M.W. and H.D. Billingsley. 1973. Watercore development in apple fruits as related to sorbitol levels in the tree sap and to minimum temperatures. J. Amer. Soc. Hort. Sci. 98:205-207.

Williams, M.W., G.C. Martin, and E.A. Stahly. 1967. The movement and fate of sorbitol- $\mathrm{C}^{14}$ in the apple tree and fruit. Proc. Amer. Soc. Hort. Sci. 90:20-24.

Yamada, H., K. Hamamoto, A. Sugiura, and T. Tomana. 1988. Effect of controlled fruit temperature on maturation of apple fruits. J. Jpn. Soc. Hort. Sci. 57:173-177. 